\title{
European universities: an interpretative history
}

Citation for published version (APA):

geuna, A. (1996). European universities: an interpretative history. MERIT, Maastricht Economic Research Institute on Innovation and Technology. MERIT Research Memoranda No. 008 https://doi.org/10.26481/umamer.1996008

Document status and date:

Published: 01/01/1996

DOI:

10.26481/umamer.1996008

Document Version:

Publisher's PDF, also known as Version of record

\section{Please check the document version of this publication:}

- A submitted manuscript is the version of the article upon submission and before peer-review. There can be important differences between the submitted version and the official published version of record.

People interested in the research are advised to contact the author for the final version of the publication, or visit the DOI to the publisher's website.

- The final author version and the galley proof are versions of the publication after peer review.

- The final published version features the final layout of the paper including the volume, issue and page numbers.

Link to publication

\footnotetext{
General rights rights.

- You may freely distribute the URL identifying the publication in the public portal. please follow below link for the End User Agreement:

www.umlib.nl/taverne-license

Take down policy

If you believe that this document breaches copyright please contact us at:

repository@maastrichtuniversity.nl

providing details and we will investigate your claim.
}

Copyright and moral rights for the publications made accessible in the public portal are retained by the authors and/or other copyright owners and it is a condition of accessing publications that users recognise and abide by the legal requirements associated with these

- Users may download and print one copy of any publication from the public portal for the purpose of private study or research.

- You may not further distribute the material or use it for any profit-making activity or commercial gain

If the publication is distributed under the terms of Article $25 \mathrm{fa}$ of the Dutch Copyright Act, indicated by the "Taverne" license above, 


\title{
European Universities: An Interpretive History*
}

\author{
by \\ Aldo Geuna \\ MERIT, University of Limburg \\ P.O. Box 616,6200 MD Maastricht, NL \\ Tel. +3143 3883865, Fax. +3143 3216518 \\ E-mail A.Geuna@MERIT.Rulimburg.NL
}

First Draft: November: 1995

This Draft: April 1996

* The useful comments and suggestions of Cristiano Antonelli, Paul David and Ed Steinmueller are gratefully acknowledge. 


\section{Introduction}

Over the 1980's and early 1990's the central relevance of knowledge in the development process has been widely recognized. The rise of a postindustrial, service-oriented society has raised new questions to which the various social sciences have tried to give answers. Economics, both with mainstream endogenous growth models and with more heterodox approaches of the economics of science and technological change has utilized the concepts of production and distribution of knowledge to explain economic growth. Notions such as knowledge-based economy, learning economy and more generally knowledge-based society have sprung from the process of cross-fertilization of sciences like economics, history and sociology. Common to all the studies, although in some left at the background more then in others, is the concern with the 'sites' where knowledge is created and transmitted. ${ }^{1}$ Following the approach of David and Foray (1994) we can identify the main institutional sites where scientific and technological knowledge is generated. They are: universities, firms, public research agencies, and private research centres. Due to the presence of externalities and spillovers, and to the development of specific transfer mechanisms, the knowledge created at a specific site in the system tends

\footnotetext{
1 With transmitted we mean both the transfer and distribution of knowledge inside and outside the 'site' of production.
} 
to percolate ${ }^{2}$, although not immediately, or completely, into other learning processes that are taking place elsewhere in the system.

Until recently, the university has played an unique and essential role in the process of knowledge creation and transmission. As clearly stressed by Perkin (1984, pp.45-46) "A knowledge-based society depends on both the constant advancement of knowledge and the reproduction of knowledgeable people as much as industrial society depends on the constant investment of capital and the reproduction of skilled managers and workers." But if so, does there exist today a place called university where not only the advancement of knowledge through research, and the internal transmission of knowledge through teaching, but also the external transmission of knowledge are realized? To what extent are these goals mutually compatible? Are there changes in societal expectations concerning the kinds of knowledge with respect to which the university should play these dual roles? Are those changes creating tensions that may result in radical transformations of the institution of the university as we know it?

According to Roger L. Geiger (1985, p.53):

\footnotetext{
2 It does not exist a preordained sequence in the percolatio. The process can be depicted as an interchange of knowledge among the various sites and not as an one way transmission.
} 
"The development of science in the modern era has taken place in a variety of institutional settings. However, since the widespread recognition of German scientific leadership in the last third of the nineteenth century, and continuing through the ascendancy of American science in the mid-twentieth, the university has served as the predominant home of science. Although this nexus between universities and research has been considered virtually axiomatic for a century, it can no longer be regarded as so today. The vast proliferation of modern science has long-since overflowed the confines of the university, while the parallel expansion of higher education has necessitated departures from the university model." 3

Due to its success both in research and in teaching, the university has grown in dimensional term --i.e number of students, number of researchers, financing. In particular, after the Second World War its rapid growth was also connected with a rise in society's expectations for economic returns. These two phenomena, the dimensional growth and the rise of expectations, put the university under strain. Topics such as compatibility between the demands of elite and mass higher education, free research enterprise versus targeted research, private versus public financing, free advancement of the knowledge frontier versus dependence from the need of the society, competition from teachingoriented and research-oriented institutions have led to counteracting pressures on the institutional organization and roles played by the university.

The historical development of the university testifies to "... its protean capacity to change its shape and function to suit its temporal and sociopolitical environment while retaining enough continuity to deserve its unchanging name" 
(Perkin, 1984, p.18). Although a large part of the literature concerned with university development has highlighted the present crisis of the university, ${ }^{4}$ when we look at its historical capacity of adaptation and at its "...special sort of cultural inheritance with idealistic, spiritual, and high-minded aspiration derived from an important philosophical and theological traditions..." (Rothblatt and Wittrock, 1993, p.1), hope rises again. The recognition of the adaptive ability of the university, highlighted by the historical perspective, enables a better evaluation of its current situation. Instead of being in a phase of loss of importance, the university is going through a period of institutional change. A complex institution like the university tends to resist re-configuration of its structure and institutional organization; thus the result of change is only observable after a long period of time. On the basis of its historical development we can depict the present situation of the university as a phase of transition and redefinition -i.e. institutional innovation- of what is however, in Perkin's words, the axial institution of modern society. ${ }^{5}$

4 See for example Gibbons et al. (1994), Hague (1991) and Scott (1984).

5 An opposing view is put forward in Gibbons et al. (1994), see especially Chapter IV. With the development of what they call Mode 2 of knowledge production, "...the institutions of higher education, the universities, in particular, will comprise only a part, perhaps only a small part, of the knowledge producing sector. They are no longer in a strong enough position, either scientifically, economically or politically, to determine what shall count as excellence in teaching and research" (Gibbons et al., 1994, p.85). A similar view is put forward in Hague (1991). 
The institutional stability, the inertia, of the university historically has led to a slow process of incremental institutional innovation. This process of institutional change can be depicted as a continuous series of adjustments to the changing environment. Unless a profound and disruptive change impelled by shifts in the external socio-political environment of the organization takes place, the roles played, rules followed, and aims to be accomplished can be traced back to the historical development of the institution. Highly diversified modern universities are the result of this process of evolution. The historical and sociological analysis of university development have highlighted a few main features --e.g. the independence from external powers of the medieval university, the pursuit of knowledge for its own sake of the nineteenth century university-that have characterized the university as a peculiar institution throughout its history. Some of these attribute are still present with different degrees of importance in the contemporary universities.

The idiosyncratic behaviours and structural specificities of contemporary universities, together with the enormous development of other institutions for higher education have made the identification of a homogeneous class including all the universities increasingly arduous. In 1990-1992 the total number of 
Higher Education Institutions ${ }^{6}$ (HEI) in the $\mathrm{EU}^{7}$ was of circa 1429 institutions (IAU 1991, 1993). Looking at the official national classifications, it is possible to subdivide them in 379 Universities and 1050 Post Secondary Institutions ${ }^{8}$ (PSI). Nonetheless, when one considers the International Standard Classification for Education (ISCED) the difference between universities and PSI becomes fuzzier (see Table 1 for students subdivision). ISCED level 5 --i.e. education at the tertiary level, first stage, of the type that leads to an award not equivalent to a first university degree-- is usually offered by PSI, but sometimes also by universities. ISCED level 6 --i.e. education at the tertiary level, first stage, of the type that leads to a first university degree or equivalent-- is normally supplied by both universities and PSI. Finally, ISCED level 7 --i.e. education at the tertiary level, second stage, of the type that leads to a post-graduate university degree or equivalent-- is usually the domain of universities, but sometimes PSI offer Master and Ph.D. degrees. Thus, degree granting specialisations do not seem relevant for justifying a division between universities and PSI.

6 Higher education institutions are institutions that offer education programmes at the tertiary level --i.e. programmes classified as either ISCED (International Standard Classification for Education) level 5, 6 or 7. For the definition of tertiary education and ISCED classification see the Glossary of OECD (1995; pp. 366-369).

7 This count does not include Austria, Finland, Luxembourg, and Sweden.

8 To calculate the number of PSI we have used an estimate of the PSI in the UK. For the selection criteria of the 379 institutions classified under the class universities see Geuna (1996). 
Table 1: $\quad$ Students by ISCED level of programme

\begin{tabular}{|l|c|c|c|c||}
\hline & Level 5 & Level 6 & Level 7 & All Levels \\
\hline B - 1990 & 123,970 & 136,664 & 15,614 & 276,248 \\
\hline D - 1990 & 22,843 & 120,125 & $* *$ & 142,968 \\
\hline F - 1990 & 454,055 & $1,065,600$ & 179,283 & $1,698,938$ \\
\hline G - 1990 & 220,802 & $1,578,592$ & $* *$ & $1,799,394$ \\
\hline Gr -1989 & 77,159 & 117,260 & - & 194,419 \\
\hline I - 1991 & 10,378 & $1,474,719$ & 48,105 & $1,533,202$ \\
\hline Ir- 1990 & n.a. & n.a. & n.a. & 90,296 \\
\hline Nl - 1990 \# & 252,346 & 181,795 & 8,653 & 442,784 \\
\hline P - 1990 & - & 182,032 & 3,730 & 185,762 \\
\hline S -1989 & 366 & $1,143,080$ & 25,695 & $1,169,141$ \\
\hline UK - 1990 & 383,026 & 706,089 & 169,073 & $1,258,188$ \\
\hline TOTAL & $1,544,950$ & $6,705,962$ & 450,160 & $8,791,340$ \\
\hline
\end{tabular}

Source: Unesco Statistical Yearbook (1993).

** The figure is included in the figure of Level 6; - Magnitude is either negligible or zero; \# It excludes the students of distant learning institutions.

When knowledge creation and transmission aspects --i.e. norms, incentives and organizational structure of the "open science" ${ }^{9}$ kind of research-- are put at the core of the analysis, a subdivision is still possible. Nevertheless, as we shall highlight at the end of the Section 2.3, the most crucial differences --e.g. research orientation, independence in the pursuit of new knowledge, availability

9 For an analytical history of the emergence of the institutions of "open science" see David (1994b); for the role played by norms, incentives and organizational structure in the creation of knowledge see Dasgupta \& David (1987, 1994). 
of funds-- are the ones between a restricted group of elite research intensive universities and a cluster of universities and PSI, and not the ones between universities and PSI. The official distinction in universities and PSI is, in general, too loose to be relevant for making useful distinctions.

\section{European Universities}

The word 'university' is increasingly employed by scholars in policy oriented studies concerned with technology transfer and university-industry relationships, ${ }^{10}$ as well as in works examining universities as sites of knowledge creation. ${ }^{11}$ It is interesting to notice that usually scholars use the word university to refer to a single type of organizational entity despite significant differences in the institutions labelled as universities. On the one hand, this is a general problem with economic thought that tends to consider heterogeneous institutions as homogeneous organizations --e.g. the use of the term firm to describe all profit-seeking business organizations. On the other hand, this is a problem peculiar to the definition of university as is explained concisely and lucidly by Rothblatt and Wittrock (1993, p.1):

10 See for example: Blume (1987), David \& Steinmueller (1995), Etzkowitz (1993), Malerba et al. (1991), OECD (1984, 1990), Stankiewicz (1986).

11 See for example: David, Mowery and Steinmueller (1994), Jaffe (1989), Mansfield (1991). 
"the problem of defining university has long preoccupied politicians, planners, reformers, academics, theologians, philosophers, historians, and litterateurs. They have often found the task impossible. So much has this been the case, especially since the eighteenth century, that universities are now subsumed under a broader if less romantic category called 'higher education'."

Still, to understand the undergoing changes in the structure, role and goals of the university, a better definition of what is the current European university is needed. Referring to the university as a group of institutions, sub-group of the class 'higher education institutions' does not add much clarity to the debate. Among the others, according to Rothblatt and Wittrock (1993, pp.3-4):

"Higher education ... is very likely a neologism of the last century. It was, and remains, imprecise. Nations do not define 'higher' in the same way, just as they do not define 'lower' education in the same way. Academic work deemed appropriate for a school in one country is inappropriate in another, and courses of study pursued at college or university in one nation are located in an 'upper secondary' or 'postcompulsory sector' in another."

The term 'higher education institutions' is not suited for the purpose of identifying a particular kind of organization. It encompasses groups of institutions that differ in relation to the country and the period of time taken into account. Therefore, we cannot usefully describe the university merely as a subgroup of 'something' that cannot be defined. It would be better simply to describe the attributes of the subclass itself.

After the Second World War the university went through a process of rapid growth and diversification. The number of students, number of researchers and the level of financing have more than quadrupled in less than thirty years. 
The elite pre-war institution has become a mass institution, mostly, but not only, concerned with research and teaching. New universities and new kind of higher education institutions, with different structures, roles and goals, have been founded. This process of increasing diversification makes problematic, if not impossible, the task of defining the university.

However, the recognition of a phase of transition and redefinition for the university does not mean that is not possible to define the university in ideal and historical terms. On the contrary, the analysis of the ideal attributes of the university and of their historical development will enable a better understanding of complex and rapidly changing circumstances.

Contemporary European Universities are the product of about 800 years of evolution. Their current situation is the result of a series of historical events. Hence an historical approach is required to fully understand the characteristics of this peculiar institution. Focusing on university contribution to social purpose and on the governance and organization of the institution, we shall develop an interpretive history of European universities. The roles played, rules followed, and aims to be accomplished of contemporary universities find their roots in the medieval traditions, in the approach to scientific discovery developed by the 
scientific societies of the late eighteenth century, and in the nineteenth century German model.

Broadly speaking, one can subdivide the historical development of the university in four different phases. First, the birth of the university. The period of time between the late twelfth and the early sixteenth century that witnessed the birth and development of a unique institution that would have assumed the name of Universitas Magistrorum et Scholarium or Studium Generale. Second, the decline period that runs from the second half of the sixteenth up to the end of the eighteenth century. Third, the recovery and German transformation, from the early nineteenth century up to the Second World War. ${ }^{12}$ Fourth, the expansion and diversification, from the end of the Second World War up to the end of the 1970's. Probably, we are now entering in a fifth phase that can be named the redefinition of the role of the university. In the following we shall examine the first, third and fourth phase in more detail.

\subsection{The birth of the university}

\footnotetext{
12 A more detailed division is offered by Björn Wittrock (1993) who subdivides the recovery and German transformation into two sub-phases: the resurrection of the university (1800-1850) and the rise of the researchoriented university (1850-1939).
} 
The idea of university is a European creation. During the Middle Ages, between the twelfth and thirteenth centuries, in certain European towns, mostly in Italy and France, a peculiar institution of higher education developed to a level of organizational and educational complexity to be consider the ancestor of the modern university. For more than three thousand years the development of various civilisations has went with the flourishing of higher learning. Nonetheless, only the medieval higher education institution, known as studium generale, "...employing regular teaching staff, offering specific courses of higher studies ... and granting certificates of accomplishment in the form of generally recognized diplomas or degrees" (Rudy, 1984, p.14), has showed a continuity through time that enables one to consider it as the predecessor of the modern university. In particular, Bologna and Paris are usually considered the oldest universities. $^{13}$

Bologna ${ }^{14}$ had a long tradition of law teaching. At the starting of the twelfth century the law schools developed into an 'university' (guild) and acquired international prestige. Only after some years other subjects raised at the level of creating other 'universities' that then associated with the one of law.

13 Bologna claims to be the first, dating its foundation in 1088. However, different investigations into the history of medieval universities have failed to produce any evidence in support of this claim (Rüegg,1992; Rashdall, 1936).

14 The following description of the universities of Bologna and Paris draws particularly heavily upon Verger (1992a), but see also Rashdall (1936) and Cobban (1975). 
Among the professional courses, medicine and not theology developed in an important way. Especially in the case of law and medicine, the students where generally adults from high social class. Coming from different European regions, they went to Bologna to specialize in a professional career. Consequently, the university of Bologna was organized as a corporation of different mono-disciplinary 'universities'. In each 'university', depending on the locality of their origin, the students were grouped into 'nations'. The students were the only members of the institution to enjoy university rights, ${ }^{15}$ while the teachers were simply hired through annual contracts.

The origins of the university of Paris are to be found in ecclesiastical and private schools that flourished in the twelfth century. The former were schools of theology, above all of them was the school of Notre-Dame with its chancellor who operated under the authority of the bishop. The latter were schools of arts, although private, they were under the direct control and exactions of the chancellor of Notre-Dame. Due to the rapid growth in the number of students and masters, a proliferation of new school and a disciplinary confusion took place. The danger of loosing the control over the subject taught, convinced the bishop and the chancellor to accept the formation of an autonomous guild of

15 In particular, only the foreign students were full members of the university. The local students did not need to be member of the university as they were citizens of Bologna, and thus they enjoyed municipal rights. 
masters. This 'university' was responsible for the organization of curricula, examinations, and faculties distinction in a way that respected the "classification and hierarchies upon which Christian knowledge had traditionally been based." Nonetheless, the compromise between the bishop and the autonomous guild of masters was fragile. In subsequent times, the direct interventions of the Pope and/or of the King ${ }^{16}$ was required to settle the dispute. The confrontation reached the point of the cessatio in 1228 (moving the institution out of the town), when the member of the arts faculties withdrew from Paris. Three years after, when Pope Gregory IX issued the bull that secured the full chartered rights to the university, the whole institution was reassembled. Due to the importance of art and theology, the students where mainly clerici and/or young students, thus the only members of the university to enjoy all of the rights and prerogatives were the teachers and the masters. ${ }^{17}$

The so-called students' universities, that sprang up mostly in the South of Europe during the fourteenth century, adopted the model (the statutes) of Bologna to the local circumstances. As in the case of Bologna, these universities generally had an important faculty of law and few other less

\footnotetext{
16 The Empire and the Papacy were struggling to assume the jurisdiction over the new education institution, thus they were available to support the 'university' one against the other.

17 The term master referred to a scholar that held a master degree in art, that is to say, that succeeded in the first two tiers of the curriculum -- i.e. apprentice and bachelor. Often he was a student of the advanced courses in theology, law and medicine, and, in the meanwhile, he taught undergraduate courses.
} 
developed faculties. In the fifteenth century, after the Great Schism (1378), the northern and the central part of Europe also witnessed a period of rapid rise in the number of new universities. These new institutions, generally created exnovo by the Emperor, Kings or Dukes, structured their organization following the Parisian model --i.e. the masters' university. ${ }^{18}$ Usually all the four faculties of art, theology, law and medicine were present in the new institutions. ${ }^{19}$

Two names were most commonly used to define the university. They were: Universitas Magistrorum et Scholarium ${ }^{20}$ and Studium Generale. In the early period the "...commonest term in texts... would seem to be universitas and not studium generale" (Verger, 1992a, p.37). More precisely, as the term universitas --i.e. the totality or the whole-- was applied to corporate bodies (guilds) of the most different sorts, "one had to specify the object to which one was referring" (ibidem). Then the name universitas magistrorum et scholarium or universitas studii. The term studium generale become the legal definition of the university only after the second half of the thirteen century. During the first

18 In the thirteenth century, Oxford and Cambridge developed following the masters' model too.

19 An idea of the dimensional university development can be found in Verger (1992a). He maintain that: "The twenty-eight (or thirty-one) universities operative in 1378 became thirty-one (or thirty-four) in 1400 and sixty-three (or sixty-six) in 1500 (Verger, 1992a, p.57).

20 It is possible to find both the term Universitas Magistrorum and the term Universitas Scholarium, in relation to the type of organizational structure utilized. Sometimes the term Universitas Studii is also used as a more general way to define the new institution. 
half of the century, studium generale was used with descriptive intent, "...the studium part indicating a school ... and generale referring ... to the ability of the school to attract students from beyond the local region" (Cobban, 1975, p.23). Only towards the end of the century did the concept of studium generale acquire a legal connotation. ${ }^{21}$

Three particular rights were connected to the status of studium generale. First, the higher education institution recognized as a studium generale was entitled to award degrees, master or doctoral degree, recognized everywhere in the Christendom. The holder of such degree had the right "to teach in any other university without undergoing further examination" (ibidem, p.27), the jus ubique docendi. ${ }^{22}$ Second, the institution was secured from the action of the local, religious and lay, authority; it was under papal or imperial protection. Third, clergy studying at a studium generale were entitled "to receive the fruit of their benefices" although non-resident. As we have showed in the case of Paris, the achievement of a certain degree of independence was the result of conflicts with both the local authority and the universal authorities --i.e. the

21 A lot of scholarly work has been dedicated to the discussion of the meaning of the terms universitas and studium generale. See, for example, Chapter I of Rashdall (1936) and Chapter II of Cobban (1975).

22 Although always associated with the status of studium generale, in the reality the jus ubique docendi has not been always acknowledged. With the increase in the number of studia generalia, the old-established universities, in the attempt to defend their monopoly position, tended to refuse the jus ubique docendi, requiring a re-examination for the candidates coming from other universities (Cobban, 1975; Brizzi \& Verger, 1990). 
Pope and the Emperor. The confrontation with the former was related to the claim of self-governing. The university opposed to the direct control and exactions of the local authority. Although located in a specific town, it refused to submit itself to the local jurisdiction, calling for special rights of universal character. To obtain them, two connected strategies were employed. On the one hand, due to the fact that the presence of the university meant an increase in wealth and importance of the town, the threat and use of the cessatio ${ }^{23}$ put pressure on the town's authorities. On the other hand, the university looked for the support of the Pope or of the Emperor, applying to universal entities to have universal rights. The protection from the Pope or the Emperor depended upon the obedience to their rules. Yet, the fact that Imperium and Sacerdotium were two conflicting powers enabled the university to retain sufficient bargaining power with both of them.

In most of the cases, the title of studium generale was granted by papal bull $^{24}$ to new institutions or to pre-existing ones that were asking for the

23 The cessatio was a serious threat because the early universities were constituted only by masters, students and a few books. Capital investments --e.g. buildings and library-- started only at the end of the thirteenth century. The frequent use of the cessatio is confirmed by the origins of different universities. For example, in the case of Vicenza (1204), Arezzo (1215), Padua (1222), Siena (c. 1246) and Pisa (1343) the foundation was linked with the migration of students and masters from Bologna.

24 In most of the cases the university status was granted by the Pope, only in few cases the privilege was granted by the Emperor. Is interesting to notice that Naples, in 1224, was the first university established by Imperial decree. It was founded to rival the pro-Papacy university of Bologna, that, even if consider with Paris the most preeminent university of the period, was invested with the same privilege by papal bull only in 1291 (Rudy, 1984; Rashdall, 1936). 
official recognition. ${ }^{25} \mathrm{Up}$ to the end of the fifteenth and early sixteenth century, in the whole Europe, the use of the term studium generale, and the connected papal bull, was the norm. ${ }^{26}$ Then, due to religious and political changes, both the terminology and the requested papal charter disappeared, with few exceptions in the catholic countries. Since the eighteenth, and more evidently, from the nineteenth century, the term universitas litterarum, with the different translations into national languages, has become the official definition of the university. Furthermore, the papal bull has been substituted with an imperial, royal or governmental charter.

As the name universitas testifies the medieval university was a peculiar kind of guild. Peculiar, in so far as a community of magistres and scholares -i.e. masters and students-- involved in the elaboration and transmission of a peculiar good: knowledge. As the other type of guild it was composed by members that freely decided to join it. It was a community with internal cohesion, articulated organization and a corporate personality. A moral and legal entity enjoying a degree of independence from external powers --i.e. Pope, Emperor, Princes, towns' rulers, etc.-- and able of continuity through time. The primary objective of this community of practitioners was the transmission of

25 Oxford, one of the initial universities, never received such a recognition.

26 Where the political power was sufficiently strong, like in the cases of the Kings of Poland, Portugal and Spain, the studium generale status was granted by the king and then confirmed by papal bull. 
knowledge from the masters to the students. The medieval university was a teaching institution responsible for the preparation for the educational, ecclesiastical, governmental and professional career. The common curriculum of the seven liberal arts, subdivided in apprentice --i.e. grammar, logic and rhetoric-- and bachelor --i.e. arithmetic, geometry, astronomy and music-- was followed by the three advanced professional courses, then postgraduate faculties, of theology, law and medicine. All of them were often "taught side by side in the same institution" the university (Perkin, 1984). The differences between the university, the studium generale, and other professional training schools were: a) its organizational status guild-like; $b$ ) its special right to aware master or doctoral degrees ${ }^{27}$ recognized everywhere in the Christendom, the jus ubique docendi; c) its ability to attract students and masters from regions (countries) other than the one of its geographical location; and $d$ ) its multidisciplinary features. The other professional schools (sometimes subsumed under the name of studium particolare), ranging from elementary to higher education schools, were under the control of the local authority (religious or lay), they served the need of a town or a limited region, and they offered only courses in few of the liberal arts and not advanced professional courses.

27 Every faculty had its own master degree, in the case of the advanced profession courses the degree was called doctores or professores. 
To better understand the late medieval development of the university, some remarks concerning the financial issue are appropriate here. ${ }^{28}$ Although the independent medieval universities were characterized by heterogeneous organizational structure a similar pattern of finance can be found. University incomes can be subdivided into internal and external sources. The former were: a) fees for matriculation and graduation; b) dispensations from the statutory conditions for degree and other dispensations; c) collectae --i.e. money collected from the students once or twice a year; and d) fines for violation of university statutes and discipline. The latter were: a) ecclesiastical benefices; b) salaries payed by Church, King, Duke, or town; c) gift and legacies; and d) grant and endowments given for the permanent support of the university. In the early period university expenses were modest, but then, due to the development and the consequent increase in capital investment (houses, buildings and library), they grew rapidly. The expenses were: a) salaries to teachers; b) administration costs; c) salaries to officials; d) law suits; e) cost of academic solemnities and religious feasts; and f) acquisition and maintenance of houses, buildings and library.

28 The following analysis of the university financing draws particularly heavily upon Gieysztor (1992) and Verger (1992b). 
Of particular interest is the way in which teachers' costs were covered. During the thirteenth century the masters that were clergy endowed with benefices did not charge fees, while fees for private teachers and clergy without (or extremely low) benefices were payed directly by the pupils. However, this system was against the belief of the Church --i.e. knowledge is a gift of God, then students do not have to pay for it. Therefore, clergy without benefits started to receive a salary covered with part of the collectae and examination fees. With a growing number of teachers and the inclusion of all the masters in the scheme, the need for external support rose rapidly. Salaries of the teachers ${ }^{29}$ started to be payed by the Church (Spain), the Commune and the Duke (Italy), and the town (Germany). In France the salary system did not develop until the end of the medieval period. Due to their expansion, the independent universities ${ }^{30}$ of the late Middle Ages could no longer be selfsupporting. Teachers' salaries and costs of acquisition and maintenance of academic buildings were to high to be covered by own resources. Kings, Dukes, and towns, in return for their support became more and more involved in the control and management of university finance.

29 There were strong discrepancies between the income of the masters of the higher faculties and the teachers of arts. The income diversity was due to differences in salary, benefices, fees, and examination fees Furthermore, the masters of the professional training schools had also non-university sources of income due to their professional activity.

30 The universities controlled by the crown were not financially independent since their foundation. 
Counter to the politically fragmented nature of medieval society the university developed as a cosmopolitan, 'super-national' institution. A common language, Latin, a common course of education and a common organization enabled the creation of an international community of masters and scholars that travelled from one institution to another enjoying in the different places the same privileges and duties. The various medieval universities were not only a peculiar kind of teaching institutions, but they all were members of a 'supernational' intellectual unity devoted to the cultivation of knowledge, enjoying a certain degree of independence from the papacy, the empire and the municipal authority.

In the late medieval period, due to political and religious changes, and to increased financial needs, the university started to loose both the 'super-national' feature and its independence from external powers. It became more local in character and dependent from the support of local powers. Connected to these changes, the first symptoms of an intellectual sclerosis emerged in the conservatism of the curriculum. Humanistic thought, with the revival of classical literature and philosophy --e.g. Cicero and Plato-- was consider dangerous for religion, thus was opposed by religious establishment. The university aligned itself to the church and tended to resist the new learning; only in the course of the sixteenth century did Humanism become accepted within the 
universities. The conservatism of the university in the late fifteenth and sixteenth centuries favoured the development of new institutions, the learned society and academies. ${ }^{31}$ These, and other institutions alternative to the university, were the centre of the development of new knowledge. In the late fifteenth and sixteenth century they were mainly concerned with literary issues, then, with the development of the Scientific Revolution and the acceptance of the Humanism by the university, they became the locus where scientific research was presented and they formed the channels through which the new knowledge was disseminated.

To avoid giving a misleading description a few observations, relevant for university development in general, are required here. Medieval universities were heterogeneous institutions sharing some common characteristics. Thus, when we speak of university conservatism, as in the above paragraph for the late medieval universities, we mean that a majority of universities resisted the change, nonetheless in some universities the new ideas developed extremely fast. Furthermore, usually part of the scholars meeting in institutions alternative to the

\footnotetext{
31 The phenomena of the academies had its birth place in Italy. In the period between 1442 and 1462 , the first three important 'academie lettararie' were founded. In 1442, in Naples was established the Accademia Pontaniana, followed in 1460 by the Accademia Romana in Rome, and finally in 1462 the famous Ficino's 'Accademia Platonica' was founded in Florence. Over the sixteenth century, the Italian model of 'accademia letteraria' spread all over Europe (Mantovani, 1991).
} 
university were also teachers at the university, ${ }^{32}$ they were aware of the new ideas, thus they were bringing the challenge inside the university. Therefore, on the one hand, the university system tended towards conservatism, but, on the other hand, the seeds of change were germinating inside it.

\subsection{The recovery and German transformation}

Over the seventeen and eighteen century universities did not play a crucial role in the advance of knowledge. On the contrary, universities were not responsive to the new idea (in particular science) brought by the Scientific Revolution and the Enlightenment, and they resisted the change. According to Willies Rudy (1984, p.87): "They [universities] sill retained narrow an antiquated curriculum and methodologies, made few contributions to thought, and opposed the ideologies spawned by the Enlightenment."

The institutions where scientific research was carried out and diffused were scientific societies and academies. At the end of the sixteenth, early seventeenth century, on the model of the literary academy, private amatorial institutions concerned with the study of science started to sprang up. The

32 Copernicus, Descartes, Huygens, Kepler, and Tycho Brahe, among the others, accomplished their major works independently of the university, nonetheless they collaborated with scholars that were teaching at the university. 
Accademia Secretorum Naturae founded in Naples in 1589 is considered the first scientific academy (Ferrone, 1992). However, only in the seventeenth century the Accademia dei Lincei in Rome (1603-1630) and the Accademia del Cimento in Florence (1657-1667) developed to a level of institutional organization (with well defined membership, hierarchical control and an international scientific community of reference) that made them the prototypes of the late seventeenth and eighteenth century societies. The strong limitations imposed by the counterreformation $^{33}$ prevented the development of the Italian academies. Scientific societies and academies flourished outside the peninsula. The private and official $^{34}$ institutions developed in Europe had essentially two organizational models, the one of the Royal Society, founded in London in 1662, and the one of the Académie Royale des Sciences, founded in Paris in 1666. The former was the model for the fellows' societies. The society was controlled and directed by its members, neither state finance, nor state interference was present. The institution was mainly a site for confrontation and verification of scientific findings, it never become a real site of scientific research. With more than 300 scientist and non-scientist fellows from all around the world and the publication of the journal Philosophical Transactions the institution gave the raise to the development of an international scientific community. The French academy was

\footnotetext{
33 See for example Galileo's trial in 1633.

34 The official institutions had a corporate status, they were legally chartered by some civil authority: Emperor, King, Prince, town, etc.. (McClellan, 1985).
} 
the model for the state academies that followed. It was a state institution for the coordination, control and development of scientific research in the kingdom. The institution was not only a site for scientific confrontation and verification, but also a place where scientific research was developed. State finance enabled the creation of laboratories and libraries, and, for the first time, scientists were payed to carry out scientific research. At the beginning of the eighteenth century, with about 200 national and foreign scientists, belonging the academy in various ways, the Académie Royale des Sciences was the dominant model of scientific organization (Ferrone, 1992; McClellan 1985).

In the interim between 1660 and the French Revolution, in Europe and in America, private and official scientific societies and academies showed an impressive increase. Over hundred institutions were active in the period (McClellan, 1985). An international scientific community, as we understand it nowadays, began to develop. A common set of norms and incentives for the pursuit of scientific knowledge --i.e. the institution of "open science"35-- was emerging. The professionalization and the development of new fields of scientific inquiry induced the development of specialized societies and academies. The resulting institutions, however, proved unable to cope with the

35 For an analytical history of the emergence of the institutions of "open science" see David (1994b); for the role played by norms, incentives and organizational structure in the creation of knowledge see Dasgupta \& David (1987,1994). 
specialization of science (McClellan, 1985). Their failure paved the way to the raise of scientific research within the university.

After circa two centuries of atrophy, the nineteenth century saw the university's recovery. In the new political, religious and scientific environment the university evolved into a new kind of institution, preserving some of the features of its medieval ancestor, and incorporating and developing methodologies and social organization of the scientific research carried out in the eighteenth century societies and academies. In the late eighteenth century the pursuit of modern scientific, and technological knowledge was not carried on within the university. The late medieval, early modern universities had not been able to cope with the changes and were relegated to a marginal role. ${ }^{36}$

In the early nineteenth century, due to the pressing needs of society, new universities were founded and the old ones underwent a process of complete renewal. In particular, in Germany, England and France new models of teaching and research institutions were developed. Although different, the German, English and French models had in common: (a) some of the features of the old medieval university; (b) the methodologies and social organization of the

\footnotetext{
36 Nonetheless, especially in Scotland, The Netherlands and Germany, there were few exceptions. For example, the universities of Edinburgh, Göttingen, Halle, and Leiden were important centres of research and training during the Enlightenment (Rudy,1984).
} 
scientific research carried out in the eighteenth century societies and academies; and (c) the new and the crucial subdivision of knowledge into disciplines. The teachers were no longer masters able to teach all the required subjects, but specialized, single-discipline professors focused on the advancement and transmission of a specific, well defined portion of knowledge. Although the German model is traditionally considered the source of this 'division of labour' approach, subject specialization originally was developed in eighteenth-century Scotland. During the Scottish Enlightenment the development of the subdivision in disciplines enabled various prominent scholars to advance the knowledge frontier of their specific subject within the structure of the university (Wood, 1994) and not outside it like it happened in the other European countries. One century after, due to the Scottish influence, the same process took place in the English universities and autonomously in the new German universities. Following these two models --i.e. the English and German ones-- the structuring of knowledge into disciplines spread to all the other European countries. Thus, the second half of the nineteenth century witnessed the emergence of a modern research-oriented university in the whole of Europe. Although with national differences, which we shall discuss below, it is possible to describe the new university as an institution committed to $a$ ) the production of knowledge for its own sake, and $b$ ) the preparation for professional careers, structured in well defined disciplines and characterized by an articulate organization and a legal 
status. The university became a national institution ${ }^{37}$ allowed to pursue the unconstrained development of knowledge but to the advantage of the nationstate $^{38}$.

The university model developed in Germany during the nineteenth century has had the greatest influence on the rise of the modern research-oriented university. Following the defeat and French occupation of Prussia, a diffuse perception of the need of innovations and reforms to regain the lost power was present. In this environment, a group of reformers succeeded in overcoming the opposition of conservative circles, and got the royal approval for the foundation of a new university in Berlin. In 1809, Wilhelm von Humboldt (1767-1835) ${ }^{39}$ and a small group of civil servants of the Ministry of the Interior ${ }^{40}$ defined the aims, structure and organization of what would have become a new model of university. As accurately summarized by Spinner (1993, p.142), this "ideal university would be an institution for the cultivation of excellence, which is free

37 This is more true for the continental countries were the university was seen as tool for the cultural, economic and social development of the nation.

38 The university should, in words of Humboldt, be "the summit where everything that happen directly in the interest of the moral culture of the nation comes together" (Wittrock, 1993, p.317).

39 It is interesting to notice that Wilhelm von Humboldt started his university studies in the Prussian University of Frankfurt an der Oder, then unsatisfied by the conservative and pedantic kind of studies offered by the university he moved to the Hannoverian University of Göttingen. As we pointed out previously (see note 36), in the eighteenth century Göttingen was one of the few European universities in which scientific research and scientific organization have flourished.

40 More exactly in the part of the ministry devoted to culture and education, that would have become the ministry for education and culture in 1817 (Spinner, 1993). 
in the internal realm of research, privileged by the State and the Law, discharged (entlastet) in relation to the normal state affairs in the broader society." At the basis of this model there is the combination of teaching and research and the idea that teachers and students are "devoted to science as such for its own sake, within the proper domain of an autonomous realm of knowledge organized according to the principles of free-self-formation" (ibidem). A new 'social organization' of science and a new classification of science developed. The concept of 'pure science', carried out within the university, and conversely 'non pure science', developed outside the university, are the results of the cognitive changes originated by the development and resistance to the new university (Wittrock 1993, Spinner, 1993).

Founded in 1810, the university of Berlin was the most genuine, and probably the only, example of the Humboldtian model of university. On the basis of this model --i.e. the union of teaching and research, and the research for its own sake-- the evolution of the German university followed other paths. "... [D]espite rather than because of the Humboldtian ideal, the German university became the embodiment of the specialized research-oriented ideal and the model for the progressive system of higher education in the other advanced societies" (Perkin, 1984, pp.34-35). The crucial feature of what is considered the paradigmatic German model is, indeed, the subdivision in specialized 
disciplines, ${ }^{41}$ that is incompatible with the "holistic thinking and broad historical cultural categories" that were inspiring the Humboldtian university. Nevertheless, the Humboldtian reform enabled "the creation of an autonomous institutional setting for intellectual activities" (Wittrock, 1993, p.320) that during the nineteenth century evolved in what is considered the institutional paradigm of a collectivity of disciplinary specialization and research-orientation in the approach to acquiring and transmitting knowledge. Thus, the development of the German university during the nineteenth century can be seen as the result of the interaction between a new social organization of science, the Humboldtian model, and a new structure of science, the spontaneous trend towards the subdivision of knowledge into scientific fields.

A crucial role for the development of the German university has been played by the state. The Prussian state, and from the 1871 the imperial state, through the ministry of education and culture, carried on an organized series of actions, in modern terms science policy actions, to develop, support and improve the university system. ${ }^{42}$ In particular, the state became the principal founder

41 The structure of the university was built around the autonomous, state supported, chair holder (Ordinarius). Director of a centre of research in which were working a number of assistants (dozent) without fix state salary, he enjoyed a large degree of independence.

42 A critical role in the development of German science policy at the end of the nineteenth century has been played by Friedrich Althoff (1837-1908). In a period of 25 years (1882-1907) he developed a complex set of policy actions that has been named the 'Althoff system'. Among the other, the foundation of technical universities and the structuring of research institutions, the Kaiser-Wilhelm-Gesellschaft, that would have become the Max-Planck Institut after the Second World War, have been extremely important for the development of the 
and financier of the university. The German state saw the university not only as the source of knowledge and then of future welfare, but also as the way to strengthen the national and cultural identity. As stressed by Wittrock (1993, p.321): "the rise of the [German] research-oriented university was largely coterminous with the formation of a modern nation-state. Universities came to be the key institutions both for knowledge production and for strengthening a sense of national and cultural identity."

As we said above, the nineteenth century witnessed the renewal and restructuring of the university system in the whole Europe. Some countries imitated the German model to a large degree, while others borrowed only some of its aspects, developing their higher education and research system on the basis of national specificity. Of particular relevance are the English and French case.

At the end of the eighteenth, early nineteenth century English universities were still characterized by being training places for Anglican clergy, and gathering places for rich students. Oxford and Cambridge were still the only two recognized institutions. ${ }^{43}$ Oxford is consider the first English university.

\footnotetext{
German research and education system. For a detailed analysis of the Althoff system see Backhaus (1993) and Brocke (1991).

43 The following brief description of the universities of Oxford and Cambridge draws heavily upon Evans (1990) and Cobban (1975).
} 
Although it was never formally recognized as a studium generale, at the end of the twelfth century was regarded as a studium generale ex consuetudine. The origin of Cambridge is usually connected with the cessatio of the Oxford university in 1209-1214/15. After the closure of the Oxford studium a considerable number of students and masters migrated to Cambridge giving the birth to the new university. The organization of both universities adapted the masters' model of Paris to the local context. Due to the low power of local bishops the universities developed higher independence, and the chancellors were nominated from the assembly of the masters (congregazio/convocazio). Although already at the end of the thirteenth century Oxford was internationally known for the study of mathematics and natural sciences, and Cambridge reach an international reputation in the humanities in the early sixteenth century, the members, both masters and students, of the two universities were mostly coming from the English islands. During the early thirteenth century, together with other institutions of higher education, Oxford and Cambridge were supported by the crown. However, at the end of the thirteenth century early fourteenth the crown favoured the two institutions giving them the monopoly of English higher education.

Under the influence of secularism and the success of German scientific and technological research, in 1828 the first purely secular institution of higher 
education in the British history, University College, London, was founded. Following this model new institutions sprang up throughout the country. In particular, the second half of the nineteenth century witnessed the development of what would then be called 'civic universities', or 'redbrick' universities: Birmingham, Leeds, Liverpool, Manchester, and so on. Contrary to Oxford and Cambridge these new institutions were more responsive to the technological and scientific needs of the country (Rudy, 1984; Wittrock, 1993), and their mission encompassed not only liberal education, but also professional education, and research. New comprehensive curriculum with utilitarian subjects such as engineering, architecture, agriculture were offered in the new institutions. Although less promptly, and keeping an elitist approach, Oxford and Cambridge also developed their scientific and technological capabilities along the line of the German research model (Perkin, 1984). Nonetheless, it was under the influence of the Scottish system, more than the German model, that English universities and colleges developed the professorial system (ibidem). Contrary to the German model, the professor was not a civil servant appointed by the state, but an employee of the independent university. Moreover, he was a member of a department, primus inter pares and not an autonomous chair holder with his 'research institute' (Perkin, 1984). As in Germany research found its place in the university, but the core of the system was the idea of a "liberal education free from narrow consideration of utility and vocational interest" (Rothblatt, 
1976; Wittrock, 1993). Together with the research function and the emphasis on liberal education the university was also serving the goal of preparing students for a professional career. In some universities there was the confluence of the different aims, while others tended to be specialized in only one. Conversely to the homogeneous and state driven German system, the English system was characterized by a high degree of institutional heterogeneity and institutional independence.

To trace the peculiarity of the French system we have to go back at the end of the eighteenth century. As previously highlighted during the eighteenthcentury Enlightenment, under the Old Regime, the French universities were playing a minor role in the process of knowledge creation and they tended to be conservative if not reactionary in their teaching. In 1793, the revolutionary authorities abolished the 22 French universities (Rudy, 1984; Verger, 1986). Two new types of institutions with a clear mono-disciplinary orientation were originated. On the one hand, independent faculties pursued the study of the liberal $\operatorname{arts}^{44}$; on the other, new schools, les grandes écoles ${ }^{45}--$ e.g. École Polytechnique (1794), École Normale Supérieure (1795), focused their research

\footnotetext{
44 "... with the exception of medicine, the faculties remained examining bodies, providing some public lectures, but they were not meant to organize formal curricula" (Frijhoff, 1992).

45 Some special institution, focused on research and on training for high managerial positions, was already existing before the revolution. For example: École des Ponts et Chaussées (1747), and École des Mines (1783).
} 
and teaching on utilitarian subjects. During the Napoleonic period a highly centralized state organization emerged. The main aim of this higher education system was "to train for state service [military or bureaucratic] citizens loyal to their prince, fatherland, and family" (Rudy, 1984; p.102). The complete control of the university was in the hands of the Ministry of Education, and in 1808 the whole public instruction was set under the Imperial University of France. This structure lasted up to 1896 when faculties were reunited in 17 provincial universities. Still, the centralized state organization did not disappear, but it persisted well into the twentieth century (Karady, 1986). All along the nineteenth century, the dominant role in research has been played by les grande écoles. These institutions, utilitarian in character, were finalized to the production of scientific and technological knowledge and they provided highly trained students for the bureaucratic and managerial carriers. Only after the refounding of the provincial universities, with the development of better research facilities, were some research activities carried out in the university. At the end of the nineteenth, early twentieth century the French system came to be characterized, on the one side, by a clear cut subdivision between grandes écoles and universities, and, on the other, by a bureaucratic state control. The institutional independence, typical of the English system, or the autonomy of the chair holder, of the German system, were impossible in the French system. 
Higher education in general was considered essentially utilitarian and at the service of national interests.

\subsection{The expansion and diversification of the European university system}

Over the period stretching from the end of the Second World War to the end of the 1970's the university went through a process of rapid growth. The four main driving forces behind this large expansion were the following. First, due to internal logic --i.e. the mechanism of subdivision and re-configuration of fields of research into new sub-disciplines and the increased reliance on instrumentation-- the process of scientific inquiry has required an enlarged number of practitioners and a wider financial involvement. Second, the successful use of scientific discoveries made during the Second World War ${ }^{46}$ set in a definitive way the 'belief' of a direct applicability of scientific findings. Governments, first in the US and then in the European countries, regarded scientific research as a source of future welfare, thus directing a large amount of financial resources towards university research. Third, in particular during the 1960's, the shift in demand for level and range of skills by industry and government together with social pressures for democratization of the university

46 See especially the Manhattan Project and the Radiation Laboratory at MIT. For a clear analysis of the governmental expectations from science discoveries generated by the war experience see Geiger (1993; Chapter 1 and Chapter 2). 
system $^{47}$ transformed the perception of the educational role of the university. The university was no more considered an elite institution open only to a minority of students usually coming from the higher classes. It became an institution open to all persons qualified by ability to attend it. The opening of new institutions, and the creation of student support schemes tried to implement this new educational role of the university. Fourth, due to the strong economic growth of the post war period, and to the demographic boom, during the 1950's early 1960's, the number of students attending secondary school increased at an extraordinary pace. Consequently, the potential demand for higher education -i.e. the number of student finishing secondary school-- expanded proportionally.

Table 2: Gross Enrolment Ratio. (\%)

\begin{tabular}{|c|c|c|c|c|c|c|c|c|c|c|c||}
\hline & $\mathbf{B}$ & $\mathbf{D}$ & $\mathbf{F}$ & $\mathbf{G}$ & $\mathbf{G r}$ & $\mathbf{I}$ & $\mathbf{I r}$ & $\mathbf{N l}$ & $\mathbf{P}$ & $\mathbf{S}$ & $\mathbf{U K}$ \\
\hline $\mathbf{9 0}$ & 9.1 & 11.4 & 7.4 & 6.1 & 3.8 & 6.6 & 8.1 & $16.7^{*}$ & 3.5 & 3.9 & 9.0 \\
\hline $\mathbf{\prime}_{\mathbf{7 0}}$ & 17.5 & 18.4 & 19.5 & 13.4 & 13.5 & 16.7 & 13.6 & 19.5 & 8.0 & 8.9 & 14.1 \\
\hline $\mathbf{8 0}$ & 26.3 & 28.6 & 25.5 & 26.2 & 17.4 & 27.6 & 20.3 & 30.0 & 11.2 & 24.2 & 20.1 \\
\hline $\mathbf{9}_{\mathbf{9 0}}$ & 38.2 & 35.6 & 39.7 & 36.1 & 25.0 & 29.8 & 33.8 & 37.6 & 22.7 & 35.5 & 27.8 \\
\hline
\end{tabular}

Source: Unesco Statistical Yearbook $(1975,1983,1993) ; * 1965$ value.

The expansion of higher education, from circa one million students in 1960 to circa nine million students in 1990 in the eleven EU countries, ${ }^{48}$

47 For the UK case see the report on Higher Education of the Robbins Committee (1963). For an analysis of the Robbins achievement see Scott (1984; Chapter 5).

48 See note 7. 
brought together a process of institutional diversification (see Table 1 for levels, and Table 2 for the gross enrolment ratio for tertiary education -- i.e. total enrolment, regardless of age, divided by the population of the age group 20-24). Mainly under the influence of the respective governments, ${ }^{49}$ the enormous increase was absorbed via the enlargement of existing universities, the creation of new universities, and the foundation of new kind of higher education institutions. Following the three-fold classification made by Martin A. Trow in $1984,{ }^{50}$ the different kind of higher education institutions can be categorized as: (1) the pre-war universities, (2) the new post-war universities, and (3) the non-university institutions of higher education or, in our words, the post secondary institutions of higher education (PSI).

Although sometimes the second and third kind of institutions are under the same institutional hat, as in the case of the German Gesamthochschulen and the comprehensive universities in Sweden, ${ }^{51}$ the diversity among the three classes becomes evident when one considers the differences in: (a) research orientation, (b) funding patterns, (c) degree-granting power, (d) organizational

49 It is only recently that Europe has developed a number of private higher education institutions. Historically, only a few private religious institutions were active.

50 See Trow, M.A., 1984, The analysis of Status, in Burton R. Clark, Perspectives on Higher Education, University of California Press, Berkeley.

51 In France in some cases the Instituts Universitaires de Technologie (IUT) are part of pre-existent universities, while in other cases they are independent institutions. 
forms, (e) teaching and training orientation, and (f) autonomy. In particular, focusing on the degree-granting power and on the research orientation, it is possible to distinguish the universities (pre-war and post-war together) from the PSI. Except for the French grande écoles and few other PSI, the university has retained the right of awarding the Ph.D. degree. The university still has a monopoly position in the highest level of education. Although Ph.D. students represent only a small fraction of the total number of students (see Table 1) they are a crucial input both for the education system, as lecturers and researchers in the higher education institutions, and for the knowledge oriented production system, as researchers in public and private research centres. Due to political choice the university, and not the PSI, became the site where the government directed a large amount of financial resources for the development of scientific research. ${ }^{52}$ Politics directed the new institutions founded by the national governments primarily to satisfy the educational demand and so, originally, they did not have any research orientation. History mattered, too, in that the pre-war universities were already the place were research was carried out, and thus, due to the accumulated capabilities, they were the most suited place to develop scientific research.

52 This observation is clearly referring only to the higher education system. After the Second World War the development of scientific and technological research took place not only within the university but also in other public and private sites. 
Having said this, is nonetheless important to acknowledge that, during the 1980's and early 1990's, the distinction between universities and PSIs has become fuzzier. Relevant for the understanding of this new trend is what the higher education literature has called the academic drift phenomena. Since their foundation PSIs have tended to emulate universities. The most important reason for this behaviour was that their teaching staff, mainly trained in the university, aimed to gain the rights and privileges of the peers working in the university. This tendency has gained strength after the budget constraints of the late 1970's. A process of increased competition for the best professors and teachers, for the most promising students, and for scarce research funds took place. This process found a fertile ground in the diffuse perception of the existence of relevant status differences. The lower status institutions (PSI) developed policies aimed at catching up with institutions of higher status (universities) that had higher funding. The consequence has been a polarization of the system in three main groups. At the top there are almost exclusively the pre-war universities. They have a higher status, more rights and privileges, and wider sources of funds. They are the sites where much of the top scientific research is carried out. A second group is composed by the majority of the new universities and some of the PSI. They are characterized by a lower status and lower funds, but they have right and privileges similar to the pre-war university. They are involved in mainly technical research usually applied and oriented to regional needs. Finally, 
at the lowest level the group of vocational PSIs that exclusively undertake teaching responsibilities. ${ }^{53}$ The national governments opposed resistance to the academic drift because it was undercutting the policy objective of a diversified higher education system containing a large component of vocational and technical education. Nonetheless, as highlighted above, the combination of budget constraints and the push towards a more market oriented approach reinforced the process of academic drift. The response of the government has then been of trying to level the system downward instead of opposing the trend of levelling upward, allowing only for few centres of excellence ${ }^{54}$. Policies of higher control an less autonomy have been developed. The higher education in toto has been made more accountable to specific aims of national policy.

An illuminating example of the above described trends is the higher education policy developed in the UK during the 1980's early 1990's. Throughout the 1980's university, polytechnic, and college budget were restructured in ways that put new pressures (and incentives) on the institutions. The actions were undertaken, on the one hand, to stimulate a process of

53 As one of the main driving forces of this process is the competition for funds, the consequent polarization is more clear in those countries, like the United Kingdom, where the higher education system is more exposed to market forces.

54 Again, this observation is more true for countries such as the UK where mission oriented policies (selective policies) are applied, while is less relevant for countries like Italy where proportional allocation policies (finanziamento a pioggia) are the norm. Still, as the UK system is becoming a potential attraction pole for the other European systems, its current implications are of general relevance. 
financial restructuring aimed to reduce costs and, on the other hand, to provide incentives, through mechanisms like quality assessment and technology foresight, by which it was hoped that better direction of research effort --i.e. more applied oriented-- would result. In 1988, with the Education Reform Act, the role of universities, polytechnic and colleges was suddenly transformed from the one of public institutions subsidized by the state into that of private suppliers of specific services. Finally, in 1993, 39 Polytechnic and Colleges have been granted university status. The old and new university are now all sharing a common identity. Thus are all competing for the same research funds and are exposed to a process of selectivity on the basis of assessment of research quality (David, Geuna and Steinmueller; 1995).

Throughout the 1960's and 1970's the EU higher education system has witnessed an impressive growth both in student and researchers numbers, and in financial commitment. Although in some of the less wealthy countries such as Greece, Ireland and Portugal the increase started only in the 1970's, the whole EU higher education system had grown five fold by the end of the period. This transformation from elite to mass higher education has put the university under strain. Part of the expansion has been absorbed by new universities and new institutions, but also the pre-war universities have seen a large increase in their size. The university structure, defined in the nineteenth century on the 
basis of the medieval guild-like model, was shaped for an elitist system and not for a mass system. In the attempt to satisfy the new demand, the old universities tried to accommodate the growing numbers. Due to the extreme need for teachers, less qualified lecturers found, first temporary, and then tenure positions in the university (Trow, 1984; Simone, 1993). The number of students attending a class increased dramatically, with a consequent decrease of the quality of the instruction. Training oriented courses for new and emerging professions were added to the traditional curricula, creating tensions in the old faculty subdivision. The lost of intellectual preeminence of faculties and departments together with the increase organizational complexity (due to the dimensional growth and to the diversification of goals) opened the way to the bureaucratization of the university. The university was no more a community of peers engaged in the production and transmission of knowledge, but a bureaucratic organization run by officials where scholars were involved in teaching and research together or only in one of the two. The budget constraints and the increased demand for accountability of the 1980's have further weakened the independence and status position of universities.

The trends and forces described in the previous paragraphs have originated a process of change in the structure of knowledge production within the university. First, although most of the prestigious universities of the pre-war 
period have retained a position of preeminence, their position tends to be limited to particular research fields rather than spanning the knowledge spectrum. Secondly, the lost of intellectual preeminence of faculties and departments has been followed by the rise of the research centre as the intellectual unit of research. This fragmentation has been supported not only by the internal logic of subdivision and re-configuration of research fields, but also by a higher degree of autonomy ${ }^{55}$ and lower constraints ${ }^{56}$ granted to the centre. Increasingly the university owes its prestige to the research centre, usually associated with a graduate school, and not to particular departments or to the undergraduate teaching. Finally, on the one hand, the process of fragmentation seems to point to a more specialized type of knowledge, while, on the other hand, the knowledge production process at the frontiers of science and technology tends to be more trans-disciplinary in character (Gibbons, 1994).

The reconciliation of the process of fragmentation with the trend towards more trans-disciplinary knowledge production is possible when ones looks at the development of the research network. ${ }^{57}$ Due to the increased complexity of the

\footnotetext{
55 The research centre enjoys a higher degree of independence in the setting up of research priorities. Furthermore, due to its flexibility, it can better exploit the external sources of financing. An extremely important advantage in a period of budget cuts.

56 Usually the researchers of the centre are less involved in under-graduate teaching.

57 For a broad approach to the development of the scientific network see Callon (1991).
} 
scientific research and to the development of cross-field research, such as in the case of information technologies and molecular biology, scholars sitting in different centres and concerned with fields of research that were traditionally consider separate, interact in the production of new trans-disciplinary knowledge. ${ }^{58}$ The rise in cross-countries and cross-disciplines scientific collaboration is connected to the development of large international scientific institutions, such as CERN, and to the increased mobility of researchers. In particular, the mobility of researchers can be realized both in physical terms -e.g. through visiting professor schemes, and by use of electronic media --e.g. through the development of telecommunication services ${ }^{59}$ such as Internet which enable intimate interaction among distant researchers.

\section{Conclusions}

The picture of the European university population drawn in the previous sections tends to confirm the view that after a period of rapid growth and a period of budget cuts and policy changes, a portion of the prestigious pre-war universities have managed to retain a position of preeminence. Whereas, the

\footnotetext{
58 For the development of international scientific collaboration see Luukkonen (1992). For the development of trans-disciplinary and public-private collaboration see Hicks (1995).

59 The development of the information and communication technologies and the forecasted fall of the telecommunication costs, down to the level of the simple access cost, can have a crucial impact on the changes that are going on in the higher education system. For example, it is possible to think in terms of interactive video-teaching at zero variable costs.
} 
large majority of the new post-war universities did not succeed in increasing their status. Although some of them tried to upgrade their status, also due to the impact of cumulative and self-reinforcement phenomena, they usually did not succeed in it. One of the reasons for their failure can be found in the so called Matthew effect. $^{60}$ A good researcher is usually attracted by centres/universities of excellence where she can find the human and physical capital that enables her to develop high level research. Doing that she will improve her quality and the overall quality of the institution, with the consequence of attracting new research funds and new high value researchers. This situation is characterized by two interrelated virtuous circles. First, a centre of excellence attracts high quality researchers that have high probability of doing valuable research increasing then the quality of the centre and therefore attracting new talented researchers. Second, a high level of human and physical capital implies a higher chance of achieving important research results, hence as a consequence of the high quality research there is an increased probability of having new research funds and therefore a possibility of expansion in the investment in human and physical capital.

60 For an economic analysis of the so-called "Matthew effect" and its implications for resource allocation see Arora, David and Gambardella (1994), Dasgupta \& David (1987, 1994), David (1994a) and Geuna (1995). For its implications on the university status see Trow (1984). For its original definition in the sociology of science see Merton (1968) 
The changes in the knowledge production emphasized at the end of Section 2.3 --i.e. 1) the old universities are no longer spanning the knowledge spectrum, 2) the rise of the research centre as the intellectual unit of research, and 3) the development of the research network-- are more likely in the pre-war institutions highly involved in scientific research. These research universities, usually elite pre-war institutions and a handful of new institutions, will shape and will be reshaped by the new structure of knowledge production. The other institutions, either involved in technological research or only teaching institutions, are only witnesses of this process.

Whatever the reasons, the outcome of the forces and trends we have described is a clear cut division between a small group of dynamic research oriented universities and a large group of mainly teaching oriented institutions. Without entering in a discussion on the value of this outcome, is nonetheless crucial to highlight the risk of a possible separation of teaching, mainly undergraduate, from research, one of the founding principle of the university. The national university developed in the nineteenth century composed by a community of mainly national peers, covering a broad spectrum of disciplines, and focused on both teaching and research tends to disappear. A new kind of institution, in its international character and in its disciplinary specialization more similar to the old medieval university, is starting to develop. 


\section{References}

Arora, A., P.A. David, and A. Gambardella, 1994, Increasing Returns to Knowledge Capital in Scientific Research, Paper Presented to the NBER Summer Workshop on Industrial Organization, Cambridge, Mass., mimeo, Urbino University, Urbino, Italy.

Backhaus, J.G. (ed.), 1993, The Economics of Science Policy: An Analysis of the Althoff System, Special issue of Journal of Economic Studies, Vol. 20, No. $4 / 5$.

Brocke vom, B., 1991, Friedrich Althoff: A Great Figure in High Education Policy in Germany, Minerva, Vol.29, No.3, pp. 269-293.

Bell, D., 1976, The Coming of Post-Industrial Society. A Venture in Social Forecasting, Harper Collins Publishers.

Blume, S., 1987, The Theoretical Significance of Co-operative research, in S. Blume et al. (eds.), The Social Direction of the Public Sciences, Sociology of the Sciences Yearbook, Vol XI.

Brizzi, G.P. and J. Verger (eds.),1990, Le Universitá dell'Europa: La nascita delle Universitá, Milan:Amilcare Pizzi Editore.

Brizzi, G.P. and J. Verger (eds.),1991, Le Universitá dell'Europa: Dal Rinascimento alle Riforme Religiose, Milan:Amilcare Pizzi Editore.

Brizzi, G.P. and J. Verger (eds.),1992, Le Universitá dell'Europa: Dal Rinnovamento Scientifico all'Etá dei Lumi, Milan:Amilcare Pizzi Editore.

Brizzi, G.P. and J. Verger (eds.),1993, Le Universitá dell'Europa: Gli Uomini e i Luoghi, Milan:Amilcare Pizzi Editore.

Callon, M., 1991, Techno-economic networks and Irreversibility, in J. Law (ed.), A Sociology of Monsters: Essays on Power, Technology and Domination, Routledge, London.

Clark, B.R. (ed.), 1984, Perspectives on Higher Education. Eight Disciplinary and Comparative Views, University of California Press, Berkeley. 
Clark, B.R. and G. Neave (eds.), 1992, The Encyclopedia of Higher Education, Pergamon Press, Oxford.

Cobban, A.B., 1975, The Medieval Universities: Their Development and Organization, Methuen \& Co Ltd, London.

Dasgupta, P. and P.A. David, 1987, Information Disclosure and the Economics of Science and Technology, Chap. 16, in G. Feiwel (ed.), Arrow and the Ascent of Modern Economic Theory, New York University Press, New York.

Dasgupta, P. and P.A. David, 1994, Towards a New Economics of Science, Research Policy, 23/5, September.

David, P.A., 1994a, Positive Feedbacks and Research Productivity in Science: Reopening Another Black Box, in O. Granstand (ed.), The Economics of Technology, Elsivier Science Publisher, Amsterdam.

David, P.A., 1994b, Reputation and Agency in the Historical Emergence of the Institutions of the "Open Science", MERIT's Research Memoranda, No. 2/94006, Maastricht, The Netherlands.

David, P.A. and D. Foray, 1994, Accessing and Expanding the Science and Technology Knowledge-base, Working Group on Innovation and Technology Policy, DSTI/STP/TIP 94(4), OECD, Paris.

David, P.A., Geuna, A. and E. Steinmueller, 1995, Additionality as a Principle of European R\&D Funding, MERIT's Research Memoranda, No. 2/95-012.

David, P.A., D.C. Mowery and W.E. Steinmueller, 1994, University-Industry Research Collaborations: managing Missions in Conflict, presented at the conference CEPR/AAAS "University Goals, Institutional Mechanisms, and the 'Industrial Transferability"of Research", 18-20 March, University of Stanford.

David, P.A. and W.E. Steinmueller, 1995, A Productive Tension: UniversityIndustry Research Collaboration in the Age of Knowledge-Based Economic Development, Stanford University Press, Stanford, CA, forthcoming.

Etzkowitz, H., 1993, Enterprises from Science: The Origins of Science-based Regional Economic Development, Minerva, Vol. XXXI, No.3, pp.326-360. 
European Commission, 1994, The European Report on Science and Technology Indicators 1994, EUR 15897 EN, Luxembourg.

Evans, R., 1990, Le Universita' di Oxford e Cambridge, in Brizzi, G.P. and J. Verger (eds.),1990, Le Universitá dell'Europa: La nascita delle Universitá, Milan:Amilcare Pizzi Editore.

Ferrone, V., 1992, Le Accademie Scientifiche, in Brizzi, G.P. and J. Verger (eds.),1992, Le Universitá dell'Europa: Dal Rinnovamento Scientifico all'Etá dei Lumi, Milan:Amilcare Pizzi Editore.

Frijhoff, W., 1992, Universities: 1500-1900, in B.R. Clark and G. Neave, The Encyclopedia of Higher Education, Pergamon Press, Oxford.

Geiger, R.L., 1985, The Home of Scientists: A Perspective on University, in Wittrock, B. and A. Elzinga (eds.), 1985, The University Research System. The Public Policies of the Home of Scientists, Almqvist \& Wiksell International.

Geiger, R.L., 1993, Research and Relevant Knowledge. American Research Universities Since World War II, Oxford University Press, Oxford.

Geuna, A., 1996, European Universities: Relationships among Age, Dimension and Science Research Quality, MERIT's Research Memoranda, 2/96-003.

Geuna, A., 1995, University Participation in Community Programmes: How Does the Selection Process Work?, MERIT's Research Memoranda, 2/95-002, Maastricht, The Netherlands.

Gellert, C. (ed.), 1993, Higher Education in Europe, Jessica Kingsley Publishers, London.

Gibbons, M. et al., 1994, The New Production of Knowledge. The Dynamics of Science and Research in Contemporary Societies, Sage Publications, London

Gieysztor, A., 1992, Management and Resources, in Rüegg, W. (ed.), 1992, A History of the University in Europe. Vol. I Universities in the Middle Ages, Cambridge University Press, Cambridge.

Hague, D., 1991, Beyond Universities. A New Republic of the Intellect, Hobart Paper 115, IEA London. 
Hicks, D., 1995, Published Papers, Tacit Competencies and Corporate Management of the Public/Private Character of Knowledge, Industrial and Corporate Change, Vol. 4, No. 2, pp.401-424.

International Association of Universities, 1991, International Handbook of Universities, Stockton Press, New York.

International Association of Universities, 1994, International Handbook of Universities, Stockton Press, New York.

Jaffe, A., 1989, Real Effects of Academic Research, American Economic Review, Vol. 79 (5), pp.957-970.

Jílek L. (ed.), 1984, Historical Compendium of European Universities, CRE, Geneve.

Karady, V., 1986, Les université de la Troisième République, in Verger, J. (ed.), 1986, Historie des Universités en France, Bibliothéque Historique Privat, Toulouse.

Luukkonen, T., O. Persson, and G. Sivertsen, 1992, Understanding Patterns of International Scientific Collaboration, Science, technology, \& Human Values, Vol.. 17, No. 1, pp.101-126.

Malerba, F. et al., 1991, The Nascent Globalization of Universities and Public and Quasi-Public Research Organizations, FAST Research in the framework of the MONITOR Programme.

Mantovani, A., 1991, Accademie Scientifiche e Letterarie, in Brizzi, G.P. and J. Verger (eds.),1991, Le Universitá dell'Europa: Dal Rinascimento alle Riforme Religiose, Milan:Amilcare Pizzi Editore.

Mansfield, E., 1991, Academic Research and Industrial Innovation, Research Policy, Vol. 20 (1), pp. 1-12.

Massit-Folléa, F. and F. Epinette, 1992, L'Europe des Universités. L'Enseignement Supérieur en Mutation, La Documentation Française, Paris.

McClellan, J.E. III, 1985, Science Reorganized: Scientific Societies in the Eighteenth Century, Columbia University Press, New York. 
Merton, R.K., 1968, The Matthew Effect in Science, Science, 5 January, 159:5663.

Neave, G. and F. Van Vught (eds.), 1991, Prometheus Bound. The Changing Relationship Between Government and Higher Education in Western Europe, Pergamon Press.

OECD, 1984, Industry and University: New Forms of Co-operation and Communication, Paris.

OECD, 1990, University-Enterprises Relations in OECD Member Countries, Paris.

OECD, 1992, Public Educational Expenditure, Costs and Financing: An Analysis of Trends 1970-1988, OECD, Paris.

OECD, 1995, Education at a Glance, OECD, Paris.

Perkin, H., 1984, The Historical Perspective, in B.R. Clark (ed.), Perspectives on Higher Education, University California Press, Berkeley.

Rashdall, H., 1936, The Universities of Europe in the Middle Ages, Oxford University Press.

Robbins Report, 1963, Higher Education, HMSO.

Rothblatt, S., 1976, Tradition and Change in English Liberal Education, Faber and Faber, London.

Rothblatt, S. and B. Wittrock (eds.), 1993, The European and American University since 1800, Cambridge University Press, Cambridge.

Rudy, W., 1984, The Universities of Europe, 1100 - 1914. A History, Associated University Press, Cranbury.

Rüegg, W. (ed.), 1992, A History of the University in Europe. Vol. I Universities in the Middle Ages, Cambridge University Press, Cambridge.

Rüegg, W. (ed.), 1992, Themes, in Rüegg, W. (ed.), 1992, A History of the University in Europe. Vol. I Universities in the Middle Ages, Cambridge University Press, Cambridge. 
Schmitt, C. (ed.), 1985-1994, History of University, Vol. V-XIII, Oxford University Press, Oxford.

Scott, P., 1984, The Crisis of the University, Croom Helm, London.

Simone, R., 1993, L'universitá dei tre tradimenti, Saggi Tascabili Laterza, Roma.

Spinner, H.F., 1993, Althoff and the Changing Constitution of Science: Bureaucratic, Economical or Cognitive?, Journal of Economic Studies, Vol. 20, No.4/5, pp. 134-166.

Stankiewicz, R., 1986, Academics and Entrepreneurs: Developing UniversityIndustry Relations, Frances Printer, London.

Teichler, U., 1988, Changing Patterns of the Higher Education System: The Experience of Three Decades, Jessica Kingsley Publishers, London.

Trow, M.A., 1984, The Analysis of Status, in B.R. Clark (ed.), Perspectives on Higher Education, University California Press, Berkeley.

Unesco Statistical Yearbook, various editions.

Verger, J. (ed.), 1986, Historie des Universités en France, Bibliothéque Historique Privat, Toulouse.

Verger, J., 1992a, Patterns, in Rüegg, W. (ed.), 1992, A History of the University in Europe. Vol. I Universities in the Middle Ages, Cambridge University Press, Cambridge.

Verger, J., 1992b, Teachers, in Rüegg, W. (ed.), 1992, A History of the University in Europe. Vol. I Universities in the Middle Ages, Cambridge University Press, Cambridge.

Williams, G., 1984, The Economic Approach, in B.R. Clark (ed.), Perspectives on Higher Education, University California Press, Berkeley.

Wittrock, B., 1993, The Modern University: The Three Transformations, in S. Rothblatt, and B. Wittrock (eds.), 1993, The European and American University since 1800, Cambridge University Press, Cambridge. 
Wittrock, B. and A. Elzinga (eds.), 1985, The University Research System. The Public Policies of the Home of Scientists, Almqvist \& Wiksell International.

Wood, P., 1994, Science, the Universities, and the Public Sphere in the Eighteenth-Century Scotland, in History of University, Vol. XIII, Oxford University Press, Oxford. 